\title{
PHOSPHORUS IN ORGANIC WASTE-SOIL SYSTEMS
}

\author{
Bárbara Fuentes, ${ }^{1}$ Nanthi Bolan, ${ }^{2}$ Ravi Naidu, ${ }^{3}$ and María de la Luz Mora..${ }^{4}$ * \\ ${ }^{1}$ Programa de Doctorado en Ciencias de Recursos Naturales, Universidad de \\ La Frontera. \\ ${ }^{2}$ Soil and Earth Sciences, Massey University, Palmerston North, New Zealand. \\ ${ }^{3}$ Centre for Environmental Risk Assessment and Remediation, University of South \\ Australia. Australia. \\ ${ }^{4}$ Departamento de Ciencias Químicas, Universidad de La Frontera. Temuco. Chile. \\ Av. Francisco Salazar 01145, P.O. Box 54-D, Temuco, Chile \\ Correo electrónico: mariluz@ufro.cl.
}

\section{Fósforo en los sistemas suelo - residuos orgánicos}

Keywords: Phosphorus, bioavailability, compost, manure

\begin{abstract}
Increases in the generation of organic wastes, in addition to decreases in natural resources, make it necessary to recycle these waste materials. In soils, the application of wastes as organic fertilizers, allows to reincorporate nutrients to the biogeochemical cycles. The application of wastes in agriculture has carried out with it problems associated with phosphorus $(\mathrm{P})$ overapplication in soils and contamination of water bodies. Phosphorus inside the waste matrix forms organic and inorganic compounds which have different bioavailabilities. The more important factors that influence the bioavailability of $\mathrm{P}$ in soils, organic wastes and soil-organic waste amendments are: the soil solution $\mathrm{pH}$, adsorption reactions, organic matter, phosphatase activity and low molecular weight of organic acids. In the wide range of organic wastes, purines and compost have been selected to illustrate the effects of the factors previously mentioned on the bioavailability of P in soils. According to the analyzed information, we can suggest that it would be necessary to implement technologies to increase the bioavailability of $\mathrm{P}$ in the waste matrix to produce an efficient organic fertilizer with high P bioavailibility when it is applied in soils.

According to the analyzed information, we can suggest that it would be necessary in the prospect future, the possibility to studynew technologies for increase the bioavailability of $\mathrm{P}$ in the waste matrix to produce an efficient organic fertilizer with high $\mathrm{P}$ bioavailibility when it is applied in soils.
\end{abstract}

Palabras Claves: fósforo, biodisponibilidad, compost, purines 


\section{RESUMEN}

El incremento en la generación de residuos orgánicos, acompañado de la disminución de los recursos naturales, crea la necesidad de reutilizar estos materiales. En suelos, la aplicación de residuos como fertilizantes orgánicos, permite reincorporar nutrientes a los ciclos biogeoquimicos. Sin embargo, la aplicación de residuos en la agricultura ha acarreado problemas de sobreaplicación de P y contaminación de cuerpos de agua. El fósforo dentro de la matriz de los residuos orgánicos forma diversos compuestos orgánicos e inorgánicos que presentan distintos grados de biodisponibilidad. En este artículo se han revisado los factores que determinan la biodisponibilidad de $\mathrm{P}$ en suelos, residuos orgánicos y suelos enmendados con residuos orgánicos. Dentro de los factores más importantes que afectan la disponibilidad de $\mathrm{P}$ se han identificado: el $\mathrm{pH}$, reacciones de adsorción, contenidos de materia orgánica y la presencia de agentes biologicos como actividad fosfatasa y ácidos organicos de bajo peso molecular. Dentro de la amplia gama de residuos orgánicos se han seleccionado purines y compost para ilustrar como afectan los factores antes mencionados a la contribución de P biodisponible en suelos. En base a la información analizada se puede sugerir que sería necesario implementar tecnologías que contribuyan a aumentar la biodisponibilidad de $\mathrm{P}$ en la matriz del residuo para producir fertilizantes orgánicos capaces de liberar P biodisponible cuando se aplica en suelos. En base a la información analizada se puede sugerir que sería necesario en el futuro estudiar la posibilidad de implementar nuevas tecnologías para aumentar la biodisponobilidad de $\mathrm{P}$ en la matriz del residuo con el fin de producir fertilizantes orgánicos capaces de liberar $\mathrm{P}$ biodisponible cuando se aplica en suelos.

\section{INTRODUCTION}

In rural areas, where economic activities are driven by the export of raw materials and food and fibre products, cultivation and livestock production have increased and patterns of land use have changed significantly. Intensive livestock production and agricultural farming practices tend to 'mine' many nutrients from soil, causing modifications in the nutrient flux and thereby resulting in decreased soil fertility, mainly due to the deficiencies in $\mathrm{P}, \mathrm{N}, \mathrm{K}$, $\mathrm{Ca}$ and $\mathrm{Mg}$. To maintain soil fertility, it is necessary to add nutrients to agricultural systems; farmers use mineral fertilizers, organic waste and various management techniques to maintain soil fertility. Nowadays, recovering nutrients by reincorporating organic wastes in farming systems is a sustainable alternative that can contribute to restoring the natural environmental equilibrium (Griffin et al., 2003). For this, it is essential to organize and optimize the use of natural resources because, although the recycling of nutrients through agricultural application of organic waste such as biosolids, compost and manure is an ecological method of nutrient recovery, other factors must be considered, such as social acceptability, soil nutrient saturation and contamination issues (Levlin et al., 2002).

Phosphorus is an essential nutrient. In spite of its wide distribution in nature, $\mathrm{P}$ is a limited resource (Adnan et al., 2003; Shimamura et al., 2003) and it is deficient in most soils (Vassilev et al., 2001). Soil P exists in various chemical forms, including inorganic $\mathrm{P}(\mathrm{Pi})$ and organic $\mathrm{P}(\mathrm{Po})$, which differ widely in their behavior and fate in soils (Shand and Smith, 1997; Turner et al., 2003a, 2003b; Hansen, et al., 2004), specifically in relation to bioavailability, as 
various forms can undergo cycling at different rates, being retained in soils or made available to plants (Chen et al., 2003; De Brouwere et al., 2003; Nwoke et al., 2003).

The problem of $\mathrm{P}$ deficiency can potentially be solved by the progressive return of organic materials to soil; however, the quantity, quality and management of this practice are fundamental factors that affect $P$ availability from residues (Kwabiah et al., 2003a). Identification of P in waste (both its organic and inorganic forms) is a fundamental prerequisite to understanding nutrient dynamics in soil-waste systems and the mechanisms responsible for the release of potentially bioavailable forms of $\mathrm{P}$ over time. For effective P recovery from organic residues incorporated in soil, it is fundamental to identify the $\mathrm{P}$ distribution patterns in residues and subsequently in soil, which will help determine the optimal conditions for $P$ release to plants. This review presents the critical factors that influence the bioavailability of phosphorus from organic waste in soil.

\section{PHOSPHORUS AS ANUTRIENT}

Phosphorus is an essential element for the metabolism of living organisms because it is a component of nucleic acids, the phospholipids that compose cellular membranes, ATP and ADP molecules and intermediate compounds of respiration and photosynthesis (Taiz and Zeiger, 1998).

Phosphorus in soil comes from both pedogenic and anthropogenic sources, the majority of $\mathrm{P}$ being introduced as mineral fertilizers (Bolan et al., 2005) or organic residues; a significant quantity of insoluble and more stable $\mathrm{P}$ can accumulate in soils with regular $\mathrm{P}$ application (Scherer and Sharma, 2002; Verma et al., 2005). Phosphorus mineral fertilizers include those which are water-soluble (fast release as superphosphate, triple superphosphate, monoammonium phosphate and diammonium phosphate), water-insoluble (slow release as phosphate rock and basic slag) or mixtures of both (partially acidulate phosphate rocks and superphosphate and mixed rock) (Bolan and Duraisamy, 2003;

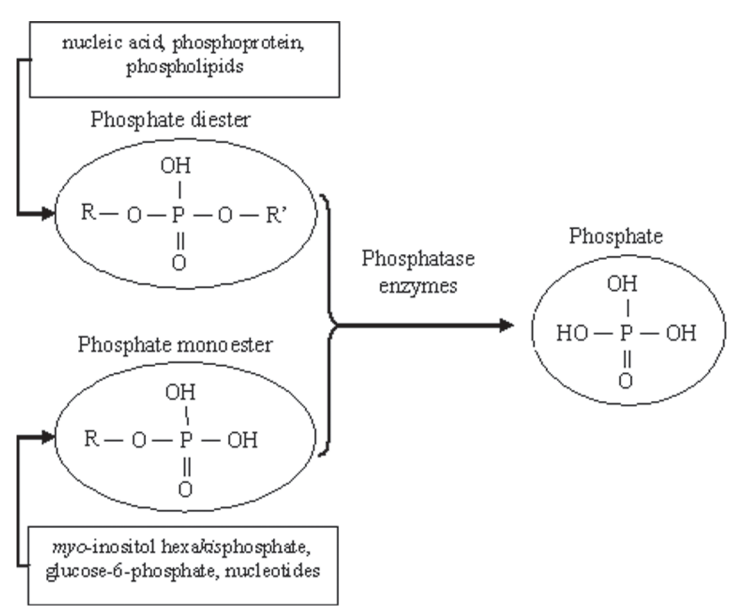

Figure 1: Phosphate release from organic phosphorus compounds.

Figura 1: Liberación de fosfato desde compuestos orgánicos de fósforos. 
Bolan et al., 2005). The main organic sources of $\mathrm{P}$ include manure, crop residues and sludge from different treatments in sustainable waste handling systems.

The most significant $\mathrm{P}$ compound in soil in terms of bioavailability is the orthophosphate anion, which is associated with readily accessible short-term availability for plants. For longer-term availability, Po compounds can be degraded to release orthophosphate (see Figure 1). Po compounds, derived from microorganisms and plant and animal waste, form part of the humified materials which are stabilized in the soil matrix. For $\mathrm{P}$ from organic compounds to be available, it needs to be hydrolyzed and mineralized by the microbial biomass, which is a fundamental process for the release of orthophosphate ions to plants (Haygarth and Jarvis, 1997; Hayes et al., 2000; Borie and Rubio, 2003; Oehl et al., 2004) and the maintenance of the P cycle in ecosystems. Through a mineralization process, Po compounds represent an important $\mathrm{P}$ source for plants and microorganisms (Thien and Myers, 1992; Makarov et al., 2005), in soil with low levels of bioavailable P (Parfitt et al., 2005) and in unfertilized cropping systems (Linquist et al., 1997). However, the effective availability of $\mathrm{P}$ compounds applied to soil from wastes depends firstly on the form of $\mathrm{P}$ added, and later on the external factors that contribute to increased or decreased availability over time.

\section{INTERACTIONS OF PHOSPHORUS IN SOIL}

\section{Physico-Chemical factors}

$\mathrm{P}$ in soil has a poor mobility due to the high reactivity of orthophosphate ions relative to the numerous soil constituents which condition this interaction and occur in the rhizosphere (Hinsinger, 2001).
The distribution of phosphorus species (organic and inorganic) in soil is determined primarily by the $\mathrm{pH}$ of the soil solution (Hinsinger, 2001) due to the variations in proton dissociation which are characterized by pKa values, which represent an important property of chemical compounds and indicate their ionization capability. Depending on the charge density, $\mathrm{P}$ ions have a tendency to form complex species with several metal cations such as $\mathrm{Ca}, \mathrm{Mg}$, $\mathrm{Fe}$ and $\mathrm{Al}$, with different bond forces forming mono-, di- and multi-dentate bonds. For example, myo-inositol hexakisphosphate in normal $\mathrm{pH}$-range soil has at least six dissociated protons which confer a high negative charge density to the molecule, causing a strong interaction with soil minerals. In soil minerals, orthophosphate anions are specifically adsorbed and form inner-sphere complexes by replacing coordinated surface $-\mathrm{OH}$ and $-\mathrm{OH}_{2}$ groups with the orthophosphate ions (Borie and Rubio, 2003; Briceño et al., 2004; Jara et $a l ., 2005)$. Therefore, the adsorption can be specific as well as electrostatic (Xu et al., 2003). P fixation and retention also occur due to high amounts of soluble and exchangeable $\mathrm{Ca}^{2+}$ resulting from reaction of $\mathrm{CaCO}_{3}$ with orthophosphate anions to form a precipitate.

Mora and Canales (1995a) indicate that the first reaction between phosphate molecules and active surface sites is associated with the mononuclear complex (labile), followed by binuclear complex (irreversible) formations. Also, the adsorption reaction can occur between orthophosphate and $\mathrm{Fe}$ or $\mathrm{Al}$ hydrous oxides (Nwoke et al., 2003), or between orthophosphate and silicate minerals.

Organic matter also affects retention of P. Organic matter adsorption on clays occurs by ligand exchange with the surface hydroxyl groups, similar to phospahte. These are therefore specifically adsorbed 
onto the surface, generating a competitive effect on P adsorption (Mora and Canales, 1995a, 1995b; Haynes and Mokolobate, 2001; Jara et al., 2005). However, organic matter could generate new adsorption sites (De Brouwere et al., 2003) allowing the stimulation of $\mathrm{P}$ adsorption through the formation of stabilization products between $\mathrm{P}, \mathrm{Al}, \mathrm{Fe}$ and organic matter

\section{Biological factors}

Soils contain low molecular weight organic acids which have one or more carboxylic groups. Some of these acids are in anionic form, such as citrate, oxalate, acetate, malate, isocitrate and tartrate. Organic acids are released by plant root exudates and microorganisms; they can also be products of the degradation of complex organic molecules (Jones, 1998; Geelhoed et al., 1999; Jones et al., 2003; Yadav and Tarafdar, 2003).

The adsorption of organic acids produces an impact on soil surface charge, thereby allowing metal cation complexation in solution and anion displacement from the soil matrix (Jones, 1998).

Organic acids have been related to nutrient mobilization, mainly utilization of insoluble $\mathrm{P}$, and therefore increase their $\mathrm{P}$ bioavailability (Bolan et al., 1994; Ström et al., 2002) with $\mathrm{P}$ adsorption decreasing due to competition for active sites for the adsorption and dissolution of light insoluble $\mathrm{P}$ compounds, e.g., $\mathrm{Ca}, \mathrm{Fe}$ and $\mathrm{Al}$ phosphates (Bolan et al., 1994; Geelhoed et al., 1999; Jones et al., 2003). However, released $\mathrm{P}$ depends on factors such as solution $\mathrm{pH}$ solution, organic acid characteristics and soil mineralogy (Bolan et al., 1994; Ström et al., 2002).

Enzymes are biological catalysts of innumerable reactions and are of great agronomic and ecological value. They are released into soil by microorganisms and plant root exudates, participate in the formation and degradation of molecules and contribute to nutrient cycling. Phosphatase is a general name used to describe a broad group of extra-cellular enzymes which catalyze the hydrolysis of both phosphate ester bonds and anhydride bonds. These enzymes play a fundamental role in the phosphorus cycle, allowing orthophosphate to be released from organic and inorganic compounds, thereby increasing the bioavailable P (Thien and Myers, 1992; Deng and Tabatabai, 1997; Rao et al., 2000).

For the development of enzymatic processes which contribute to increasing the pool of bioavailable orthophosphate ions, several kinds of phosphatases are needed that are selected for different phosphorus compounds. Phosphatase enzymes studied in soil include phytases, acid and alkaline phosphatases, phospholipase and pyrophosphatase.

Phytases have an established role in the phosphate release from myo-inositolhexakisphosphate. Soil and water microorganisms are capable of hydrolyzing phytic acid through this enzyme (Pandey et al., 2001).

Acid phosphatase and alkaline phosphatase are orthophosphoric monoester phosphohydrolases (Deng and Tabatabai, 1997; Pant and Warman, 2000) that hydrolyze compound-type orthophosphate monoesters.

Phospholipase and nuclease are orthophosphoric diester phosphohydrolases (Deng and Tabatabai, 1997; Pant and Warman, 2000) that hydrolyze compoundtype orthophosphate diesters.

Inorganic pyrophosphatases act on acid anhydride bonds in phosphoryl-containing anhydrides (Deng and Tabatabai, 1997). 


\section{PHOSPHORUS IN SOIL FROM ORGANIC AMENDMENTS}

The incorporation of organic residues can improve soil conditions (Mokolobate and Haynes, 2002; Pypers et al., 2005) making an increase in $\mathrm{P}$ availability possible. Borie et al. (2002) indicated that crop residues are applied to the soil as a source of nutrients for plants, a practice that fits in well with the current world-wide trends towards resource conservation in agriculture, and particularly with the growing interest of local farmers in alternative agricultural practices, such as organic farming and zero or reduced tillage.

The improvement in $\mathrm{P}$ availability following residue amendment depends on residue characteristics which reduce $P$ adsorption strength in soils (Haynes and Mokolobate, 2001; Pypers et al., 2005) and the bioavailability of $\mathrm{P}$ compounds incorporated into the soil. Organic matter in residues contains significant quantities of Po and, during mineralization, orthophosphate is released into the soil solution. In addition, inorganic and organic products are generated during the partial decomposition of organic waste, and humic substances and organic acids can be adsorbed into soil surfaces, decreasing the potential $\mathrm{P}$ adsorption by blocking sites for the formation of complexes with $\mathrm{Al}, \mathrm{Fe}$ and $\mathrm{Ca}$ (Iyamuremye et al., 1996b; Haynes and Mokolobate, 2001; Akhtar et al., 2002, Mkhabela and Warman, 2005).

Iyamuremye et al. (1996b) indicated that P-rich residues resulted in a significant increase in the $\mathrm{P}$ pool available (resin and $\mathrm{NaHCO}_{3}$ ), readily mineralizable Po $\left(\mathrm{NaHCO}_{3}\right)$ and the chemisorbed $(\mathrm{NaOH})$ fractions in the soil. The main mechanisms (which are simultaneous) involved in enhancing $\mathrm{P}$ availability are: orthophosphate incorporation, a rise in $\mathrm{pH}$ accompanied by $\mathrm{P}$ solubilization, production and release of organic anions, increased enzymatic activity, incorporation of organic matter and complexation of exchangeable ions such as $\mathrm{Al}^{3+}, \mathrm{Fe}^{3+}, \mathrm{Ca}^{2+}$ and $\mathrm{Mn}^{2+}$. Kwabiah et al. (2003b) indicated that, plant material input would modify bioavailable pool of $\mathrm{P}$ due to changes in the release of $\mathrm{P}$ from soluble $\mathrm{P}$ fractions, changes in immobilization rates of $\mathrm{P}$ fractions and changes in the adsorptiondesorption capacity of the soil amendment.

Organic waste incorporation,specifically compost and manure, increases $\mathrm{pH}$ values in mixed waste-soil. This $\mathrm{pH}$ increase can be associated with specific adsorption of organic molecules by ligand exchange with the release of $\mathrm{OH}^{-}$ions during organic matter mineralization, proton consumption by functional groups associated with organic materials, proton consumption during decarboxylation of organic acid anions and the release of $\mathrm{OH}^{-}$during reduction reactions (Mokolobate and Haynes, 2002). Iyamuremye et al. (1996a) indicated that manure and alfalfa residues caused the highest increase in $\mathrm{pH}$ values, averaging more than 1 unit in soil at 28 days and also causing exchangeable $\mathrm{Al}$ reduction in soil. Pypers et al. (2005) found that organic amendment significantly increased soil $\mathrm{pH}$. Soil samples with initial pHs of 4.97 and 4.39 increased $0.48-0.67 \mathrm{pH}$ units on the first day of application; on the third and seventh days after residue application, $\mathrm{pH}$ readings were 5.95 and 5.72, respectively. Sharpley et al. (2004) investigated soil with varying manure application histories and found that $\mathrm{pH}$ was significantly greater in manured soils than in untreated soils, presenting differences in a range of 1.5 units to 0.4 units, using poultry litter and swine slurry manure respectively; moreover, organic carbon, exchangeable $\mathrm{Ca}$ and total $\mathrm{P}$ increased in soil amendment as well. Pypers et al. (2005) determined that extractable $\mathrm{Al}$ concentrations in soil were considerably reduced by organic 
amendment (green residues) from 1.6 and $2.3 \mathrm{cmol}_{\mathbf{c}} \mathrm{kg}^{-1}$ to 0.63 and $0.72 \mathrm{cmol}_{\mathbf{c}} \mathrm{kg}^{-1}$ on the first day. Linear regression analysis further revealed a significant positive correlation between $\mathrm{pH}$ increase and reduction of exchangeable $\mathrm{Al}$, which favors orthophosphate anions in soil solution.

It has been proven that organic waste incorporated into soil has an influence on the composition and enhancement of microbial biomass, and therefore produces changes in enzymatic activity (Speir et al., 2004). Oehl et al. (2001) found that organically cultivated soil revealed higher microbial biomass than conventionally cultivated soil and non-fertilized soil, indicating that microbial $\mathrm{P}$ in organically cultivated soil $\left(17.6-16.5 \mathrm{mg} \mathrm{kg}^{-1}\right)$ was higher than conventionally cultivated and non-fertilized soil $\left(9.0-8.0 \mathrm{mg} \mathrm{kg}^{-1}\right)$. The organic field had a higher microbial biomass content and activity than soils of a conventionally cropped field. Marinari et al. (2006) used chemical and microbiological properties as indicators of soil quality after 7 years of organic and conventional management methods. The field under organic management showed significantly better soil nutritional and microbiological conditions, with increased levels of available phosphorus and acid phosphatase activity. Garcia-Gil et al. (2000) determined that the long-term microbial biomass enhancement in soil with organic amendments was mainly due to the microbial biomass in the organic residues and the addition of carbon substrate, which stimulates indigenous soil microbiology.

It is important to highlight that organic acids formed during organic waste decomposition by microbial degradation have a significant effect on the $\mathrm{P}$ adsorption- desorption dynamics (Iyamuremye et al., 1996c). This is likely the main mechanism involved in the reduction of $\mathrm{P}$ adsorption. These organic anions compete with orthophosphate for sites on soil surfaces and are also able to replace $\mathrm{P}$ bound to soil surfaces, producing an increase in $\mathrm{P}$ availability (Pypers et al., 2005). Iyamuremye et al. (1996c) reported malic, malonic, maleic, succinic, formic, citric and acetic acids in soil solution samples amended with organic residues and determined that citric acid affects the speciation of $\mathrm{Al}, \mathrm{Fe}$ and $\mathrm{P}$ by forming complexes with these metals, preventing the formation of gibbsite, goethite and $\mathrm{P}$ precipitation.

\section{PHOSPHORUS IN ORGANIC WASTES}

With the aim of reutilizing nutrients and diminishing organic residue disposal in landfills, it has been necessary to recycle residues and agricultural land application is one alternative (Balmér, 2004; Mkhabela and Warman, 2005). The advantage of using organic waste in agriculture is that it contains organic matter and macro- and micronutrients which may be recovered and reincorporated into natural cycles.

Organic matter in manure generates changes in chemical, physical and biological soil amendment properties (Wienhold, 2005) because it facilitates and increases cationic exchange, increasing $\mathrm{pH}$, improving the soil structure and increasing water-holding capacity and modifies microbial activity. However, it may also influence the fixation of nutrients and consequently decrease bioavailability. 
Table 1: Content of total phosphorus in organic residues.

Cuadro 1: Contenidos de fósforos total en residuos orgánicos.

\begin{tabular}{|c|c|c|}
\hline Organic residue & Total P ( $\left.\mathrm{g} \mathrm{kg}^{-\mathbf{l}}\right)$ & Reference \\
\hline \multirow[b]{2}{*}{ Beef manure } & 2.94 & Iyamuremye et al. 1996 a \\
\hline & 4.02 & Griffin et al. 2003 \\
\hline \multirow{7}{*}{ Dairy manure } & 1.6 & Garcia-Gil et al. 2000 \\
\hline & $4.9-8.9$ & Ebeling et al. 2002 \\
\hline & 4.35 & Griffin et al. 2003 \\
\hline & $4.1-18.3$ & He te al. 2004 \\
\hline & $3.5-9.8$ & Sharpley et al. 2004 \\
\hline & 11.00 (solid) & Hansen et al. 2004 \\
\hline & $0.05-0.12$ (lagoon) & Hansen et al. 2004 \\
\hline \multirow{4}{*}{ Poultry manure } & 26.21 & Leinweber et al. 1997 \\
\hline & 21 & Mokolobate and Haynes, 2002 \\
\hline & 23.60 & Griffin et al. 2003 \\
\hline & $25.2-27.8$ & Sharpley et al. 2004 \\
\hline \multirow{3}{*}{ Swine manure } & 16.22 (liquid) & Leinweber et al. 1997 \\
\hline & 24.69 & Griffin et al. 2003 \\
\hline & 29.7 & Sharpley et al. 2004 \\
\hline Municipal solid & 5.0 (compost) & Garcia-Gil et al. 2000 \\
\hline waste & $2.9-5.6$ & Mkhabela and Warman, 2005 \\
\hline CSUW & $2.25-7.19$ & Frossard et al. 2002 \\
\hline CSUW and WW & $2.09-3.43$ & Frossard et al. 2002 \\
\hline $\begin{array}{l}\text { Anaerobic sewage } \\
\text { sludge }\end{array}$ & 38.3 & Akhtar et al. 2002 \\
\hline
\end{tabular}

CSUW: compost solid urban waste. WW: woody waste.

The over-application of nutrients principally $\mathrm{N}$ and $\mathrm{P}$ - could pose a risk to the environment. Table 1 indicates total $\mathrm{P}$ values in organic wastes. In this area, $\mathrm{P}$ species and quantities in organic waste vary and therefore behave differently when applied to soil. It has been documented that organic waste incorporation causes changes in $\mathrm{Pi}$ and $\mathrm{Po}$ soil fraction distribution patterns. Baeza (2001) has investigated the 
effects of applying fresh cow dung over $\mathrm{P}$ pools in acid Chilean Andisol. P pools in the soil change due to the breakdown of cow dung. The labile-P fraction $\left(\mathrm{P}-\mathrm{NaHCO}_{3}\right)$ has a short-term increase after dung application in the $0-10 \mathrm{~cm}$ depth soil. The $\mathrm{P}-\mathrm{NaHCO}_{3}$ fraction increased from 69 to $72 \mathrm{mg} \mathrm{kg}^{-1}$ in 60 days. Then, this fraction decreased 10 $\mathrm{mg} \mathrm{kg}^{-1}$ due to microbial activity and $\mathrm{pH}$ change. From 120 to 180 days, $\mathrm{P}-\mathrm{NaHCO}_{3}$ recovered to its original level. Scherer and Sharma (2002) indicated that bioavailable $\mathrm{P}\left(\mathrm{H}_{2} \mathrm{O}-\mathrm{P}\right)$ increased in all treatments when compost, manure and sewage sludge were applied to soil (Table 5). However, $\mathrm{P}$ bioavailability over time has not been studied sufficiently, as available $\mathrm{P}$ varied depending on mineralization immobilization rates and fixation reactions in soil.

\section{Phosphorus in manures}

A common and traditional practice has utilized manure as an organic fertilizer or soil improver due to its contribution of organic matter and nutrients, mainly nitrogen and phosphorus (Rebollar and Mateos, 1999; Malley et al., 2002; Ajiboye et al., 2004; He et al., 2004; Speir et al., 2004; Wienhold, 2005).

Recently, intensified livestock production has generated an increased production of organic residues and environmental regulations have been adopted for the application of manures in agriculture (Pandey, et al., 2001), as they are a diffuse source of pollution, with $\mathrm{P}$ in particular being directly associated with eutrophication in bodies of water (Haygarth and Jarvis, 1997; Gale et al., 2000; Withers et al., 2001; Ebeling et al., 2002; Hodgkinson et al., 2002; Ajiboye et al., 2004; He et al., 2004).

In 1997, Haygarth and Jarvis demonstrated a significant relationship between runoff discharge and total phosphorus loss, indicating that mechanisms such as hydrolysis, Po mineralization and the erosion of particulate $P$ may be important for releasing P from soils. Manure is applied to soils according to the nitrogen needs of the plants. The N/P ratio in manure is low, which indicates that it contains more $\mathrm{P}$ than is needed by most crops. As a result, there is a surplus of $\mathrm{P}$ that goes unused (Atia and Mallarino, 2002; Nelson et al., 2003; Wienhold, 2005).

For adequate $\mathrm{P}$ handling of animal residues, it is necessary to know the $P$ compound, dynamics and transformation in waste and soil amendments. DeRouchey et al. (2002) proposed ensuring appropriate management of livestock waste by providing nutrient profiles of various manure types to help livestock operators accurately apply manure to their land. This practice allows crops or forages to utilize nutrients from the manure, thus decreasing the need for chemical fertilizer.

Phosphorus in manures can vary widely depending on animal physiology, species and age, composition of diets, duration of manure storage, moisture content and type of bedding material (Atia and Mallarino, 2002; McDowell and Stewart, 2005). Hansen et al. (2004) affirmed that total $\mathrm{P}$ quantity and the forms of organic $\mathrm{P}$ in manure will depend on the nature of the animal manure and the type of storage (see Table 1). Atia and Mallarino (2002) pointed out that the aforementioned variations, in addition to factors such as reapplication treatment, climate and soil characteristics, can influence $P$ availability.

However, the main differences in $\mathrm{P}$ quantity and species in manures are the product of $\mathrm{P}$ content variation in the diet (Barrow et al., 1975), where $\mathrm{P}$ is added as an orthophosphate supplement or a vegetable ingredient that contains $P$ in ATP, nucleic acids, phospholipids, phosphoproteins and phosphoglucides. Among the 
phosphoglucides, phytic acid was the most important with percentages of $60-80 \%$ of total P in grain (Rebollar and Mateos, 1999). Monogastric animals, such as pigs and poultry, possess small quantities of phytase to efficiently digest phytate in their feed. Hence it is considered that $\mathrm{P}$ from phytate should not be used for these animals, as they excrete large amounts of $\mathrm{P}$ in the form of phytic acid (Pandey, et al., 2001; Malley et al., 2002). However, He et al. (2004) determined from 13 dairy manures that phytate was present as the major hydrolyzable Po compound and DNA was low in all $\mathrm{P}$ fractions analyzed.

Phytase research has recently intensified with the aim of incorporating it into the livestock diet in order to take advantage of the phytic acid. This would mean a decrease of $\mathrm{Pi}$ supplementation in feed, and consequently a decrease in fecal excretion. Phytase supplementation in animal feed can reduce the amount of $\mathrm{P}$ in manure up to approximately 30\% (Pandey et al., 2001). Turner et al. (2002) discussed the agronomic advantages of phytase supplements in animal diets and the environmental benefits. They agreed that phytase supplements can reduce the concentration of total $\mathrm{P}$ in manures, but the corresponding changes in manure-P composition may have implications for $\mathrm{P}$ transfer to bodies of water; by transforming inositol phosphate (which is adsorbed in the soil) into $\mathrm{Pi}$, it runs off easily into bodies of water.

Phosphorus recovery from liquid manure is an attractive technology when the application to land is risky. Greaves et al. (1999) revised the potential for P recovery from animal manures as a method of increasing the sustainability of the global $\mathrm{P}$ cycle, indicating that $\mathrm{P}$ recovery is likely to require a process for extraction and later conversion to a useful product. Burns et al. (2003) highlighted phosphorus precipitation in manure prior to land application as offering the potential to recover excess phosphorus from animal manures and move it to cropping areas that require phosphorus fertilizer input. Szögi et al. (2006) have developed a technology for P recovery from swine manure. These technologies add calcium hydroxide to precipitate $\mathrm{P}$, obtaining sludge with a high moisture content which is rich in calcium phosphate as a final byproduct. It has the potential to be reused as fertilizer, but it would first be necessary to dehydrate it in order to transport it economically.

Nevertheless, for managing technologies that allow optimum recycling of $\mathrm{P}$ it is necessary to know the $\mathrm{P}$ fractions present in different manure types and their behaviors in soil. The conventional methodologies for $\mathrm{P}$ fractionation in soil proposed by Hedley et al. (1982) have been used to study $\mathrm{P}$ availability in different residues. In the Hedley procedure, soil or waste is sequentially extracted with $\mathrm{H}_{2} \mathrm{O}$ or resin, $\mathrm{NaHCO}_{3}, \mathrm{NaOH}, \mathrm{HCl}$ or $\mathrm{H}_{2} \mathrm{SO}_{4}$, and residual $\mathrm{P}$ is extracted by acid mixture (nitricperchloric). Use of this approach often assumes that similar forms exist in wastes, although the matrices of manures are based on organic residues while soils are dominated by mineral phases (Toor et al., 2006). Table 2 shows some techniques for $\mathrm{P}$ fractionation from organic wastes. Investigators have recently analyzed $P$ speciation in manures and factors that condition $\mathrm{P}$ availability. Leinweber et al. (1997) performed $\mathrm{P}$ fractionation in manure (liquid pig and chicken) and determined that of total P, 11 and 29\% were resin extract, 13 and $10 \%$ were $\mathrm{NaHCO}_{3}$ extract, 10 and $3 \%$ were $\mathrm{NaOH}$ extract, 27 and $17 \%$ were $\mathrm{H}_{2} \mathrm{SO}_{4}$ and 39 and $41 \%$ were residual for liquid pig and chicken manure, respectively. McDowell and Stewart (2005) examined P fractions in the dung of pastoral grazing animals (dairy cattle, deer and sheep). The results of the fractionation indicated that $\mathrm{P}$ 
was mainly available in fresh samples, such as in water $(15-36 \% \mathrm{Pt})$ and in bicarbonate $(36-45 \% \mathrm{Pt})$. Less $\mathrm{P}$ was distributed in the more recalcitrant fractions: $\mathrm{NaOH}(17-19 \%$ $\mathrm{Pt}), \mathrm{HCl}(4-11 \% \mathrm{Pt})$ and residual $(8-10 \%$ $\mathrm{Pt})$ "']
Griffin et al. (2003) analyzed changes in soil produced by different manure applications (beef, dairy, poultry and swine) and indicated that all extractable soil $\mathrm{P}$ pools changed over time. All $\mathrm{P}$ fractions declined rapidely after manure application,

Table 2:Reagents used for fractionation of phosphorus in organic wastes.

Cuadro 2: Reactivos utilizados para fraccionamiento de fósforo en residuos orgánicos.

\begin{tabular}{|c|c|c|}
\hline Residue & Fractionation & Reference \\
\hline Dairy manure & $\begin{array}{l}\text { Lipid phosphorus (Ether-alcohol); total acid } \\
\text { soluble P (trichloroacetic acid); residual } \\
\left(\mathrm{H}_{2} \mathrm{SO}_{4}-\mathrm{H}_{2} \mathrm{SeO}_{3}-\mathrm{H}_{2} \mathrm{O}_{2}\right)\end{array}$ & $\begin{array}{l}\text { Barnett, } \\
\text { 1994b }\end{array}$ \\
\hline Sewage sludge & $\mathrm{NH}_{4} \mathrm{Cl}, \mathrm{NaOH}, \mathrm{HCl}$ and residual-P & $\begin{array}{l}\text { Rydin, 1996; Scherer } \\
\text { and Sharma, } 2002\end{array}$ \\
\hline $\begin{array}{l}\text { Liquid pig manure, dry } \\
\text { poultry manure }\end{array}$ & $\begin{array}{l}\text { Resin; } \mathrm{NaHCO}_{3} ; \mathrm{NaOH} ; \mathrm{H}_{2} \mathrm{SO}_{4} ; \text { Residual } \\
\left(\mathrm{HCl}-\mathrm{HF}-\mathrm{HNO}_{3}-\mathrm{H}_{2} \mathrm{O}_{2}\right)\end{array}$ & Leinweber et al. 1997 \\
\hline Compost & $\begin{array}{l}\text { Deionizer water; } \mathrm{NaHCO}_{3} ; \mathrm{NaOH} ; \mathrm{HCl} \\
\text { and residual }\end{array}$ & $\begin{array}{l}\text { Frossard et al. 2002; } \\
\text { Scherer and Sharma, } \\
2002\end{array}$ \\
\hline Farmyard manure & $\begin{array}{l}\text { Deionizer water; } \mathrm{NaHCO}_{3} ; \mathrm{NaOH} ; \mathrm{HCl} \\
\text { and residual }\end{array}$ & $\begin{array}{l}\text { Scherer and Sharma, } \\
2002\end{array}$ \\
\hline Swine manure & Deionizer water; $\mathrm{NaHCO}_{3} ; \mathrm{NaOH}$ and $\mathrm{HCl}$ & He et al., 2003 \\
\hline $\begin{array}{l}\text { Biosolid, hog, dairy } \\
\text { and beef manure }\end{array}$ & Deionizer water; $\mathrm{NaHCO}_{3} ; \mathrm{NaOH}$ and $\mathrm{HCl}$ & Ajiboye et al., 2004 \\
\hline $\begin{array}{l}\text { Liquid lagoon and solid } \\
\text { manure }\end{array}$ & $\begin{array}{l}\text { Exchangeable } \mathrm{P}\left(\mathrm{Mg}\left(\mathrm{NO}_{3}\right)_{2}\right) ; \mathrm{P} \text { associated } \\
\text { with calcium }\left(\mathrm{NaCH}_{3} \mathrm{COO}\right) ; \mathrm{P} \text { associated } \\
\text { with organic matter }(\mathrm{NaClO}) ; \mathrm{Fe} \text { oxides } \\
\text { (citrate, dithionate and bicarbonate) and } \\
\text { residual }\left(\mathrm{HNO}_{3} / \mathrm{H}_{2} \mathrm{SO}_{4} \text { and } \mathrm{HF}\right)\end{array}$ & Hansen et al. 2004 \\
\hline Dairy manure & $\begin{array}{l}\mathrm{H}_{2} \mathrm{O} \text { or resin; } \mathrm{NaHCO}_{3} ; \mathrm{NaOH} \text { and } \mathrm{HCl} \text { or } \\
\mathrm{H}_{2} \mathrm{SO}_{4}\end{array}$ & He et al., 2004 \\
\hline $\begin{array}{l}\text { Fresh and Dry Dung } \\
\text { Dairy, deer, sheep }\end{array}$ & $\begin{array}{l}\mathrm{H}_{2} \mathrm{O} ; \mathrm{NaHCO}_{3} ; \mathrm{NaOH} ; \mathrm{HCl} \text { and residual } \\
\left(\mathrm{K}_{2} \mathrm{~S}_{2} \mathrm{O}_{8} \text { and } \mathrm{H}_{2} \mathrm{SO}_{4}\right)\end{array}$ & $\begin{array}{l}\text { McDowell and } \\
\text { Stewart, } 2005\end{array}$ \\
\hline Sludge & $\mathrm{H}_{2} \mathrm{O}, \mathrm{NaHCO}_{3}+\mathrm{Na}_{2} \mathrm{~S}_{2} \mathrm{O}_{4}, \mathrm{NaOH}$ and $\mathrm{HCl}$ & Ding et al. 2005 \\
\hline
\end{tabular}


specifically $\mathrm{H}_{2} \mathrm{O}-\mathrm{P}$ or $\mathrm{CaCl}_{2}-\mathrm{P}$, with $\mathrm{P}$ concentration stabilizing within 14 to 21 days of amendment. These declines exhibited differences according to the $\mathrm{P}$ source, mainly due to the contributions of water soluble $\mathrm{P}$ of each manure.

Hansen et al. (2004) investigated P forms in manure stored in solid form or in a lagoon, by means of $\mathrm{NaOH}-\mathrm{EDTA}$ extraction and ${ }^{31} \mathrm{P}$ NMR. Their results showed $\mathrm{P}$ compounds in solid and liquid manure were similar, indicating that about $30 \%$ of the total $\mathrm{P}$ is in organic form. The primary forms extracted from solid and lagoon manures were orthophosphate (63.3 and $58.4 \%$, respectively), pyrophosphate (3.5 and $7.1 \%$, respectively), the monoester phytic acid (15.6 and $10.8 \%$, respectively), other monoester (14.4 and $20.1 \%$, respectively) and diester as phospholipids $(1.8 \%)$ and DNA $(0.9$ and $1.8 \%$, respectively) and phosphonates $(0.5 \%)$. Laboski and Lamb (2003) determined the relative effectiveness of manure and fertilizer for increasing $\mathrm{P}$ availability in soil. However, $P$ in manure was always significantly more available than $\mathrm{P}$ in fertilizer for the majority of soils after 1 and 9 months of incubation. This behavior could be explained because the Po fractions in manure are composed mainly of high molecular weight compounds, probably DNA, polyphosphates and inositol phosphate, which can be adsorbed onto the soil surface and contribute to the release of Pi bound to the surface. Moreover, organic acids produced during microbial degradation compete with $\mathrm{P}$ manure for adsorption sites on soil, causing $\mathrm{P}$ manure to be more available. Scherer and Sharma (2002) indicated the positive effect of farmyard manure on $\mathrm{P}$ availability is probably due to the organic anions produced during organic matter decomposition, which can act as chelating agents for $\mathrm{Fe}$ and $\mathrm{Al}$ ions in manure, blocking potential sites for
P adsorption. Sharpley et al. (2004) reported that $\mathrm{P}$ concentrations in inorganic fractions, organic fractions and residual $\mathrm{P}$ were significantly greater in soils receiving manures compared with untreated soil. However, their results revealed a relative increase in inorganic $\mathrm{P}$ forms compared with organic P. The overall change in inorganic $\mathrm{P}$ comprised 26 to $57 \%$ of total $\mathrm{P}$ in untreated soil and increasing to 49 to $80 \%$ of total P in treated soils.

\section{Phosphorus in compost}

Compost is a simple and economic biotechnology for organic waste treatment, with its high content of organic matter and high nutrient concentration which can be taken up by a crop (Traoré et al., 1999; Garrido et al., 2002; Speir et al., 2004). The most important factor affecting the successful use of compost for agricultural practices is the degree of maturity and stability (both terms are defined as the degree of decomposition of organic matter). However, maturity refers to the rate of decomposition of phytotoxic organic substances and compost stability is related to the activity level of the microbial biomass (Benito et al., 2003).

Composting is an aerobic process, where biological exothermic oxidation of organic matter is converted into a final stable humified product. Formed by a dynamic and rapid succession of microbial populations, this process can be developed in static piles, rows or reactors. Composting is facilitated under the following conditions: $\mathrm{pH}$ between 5 and 11, C:N between 30 and 40 and humidity between $40 \%$ and $65 \%$ (Garrido et al., 2002). Frossard et al. (2002) indicated that understanding compost properties is essential for optimizing its recycling. García-Gil et al. (2004) indicated that the effect of compost on the elemental and functional composition of humic acid in soil 
is dependent on amendment rate and time application management, which determine beneficial changes in the acid-base properties of amended soil and the enhancement of its buffering capacity. This experience highlights the importance of organic matter for maintaining $\mathrm{pH}$, which is directly related to $\mathrm{P}$ availability.

The $\mathrm{P}$ content in compost is quantified as total P, but within this total neither the quantities nor the $\mathrm{P}$ species that are available are entirely clear. Compost application in intensive cropping system soils often exceeds $\mathrm{P}$ uptake owing to an accumulation of $\mathrm{P}$ species which are unavailable or not readily available. It has been determined that high levels of total $\mathrm{P}$ in soil amended with compost increased fixed-form $\mathrm{P}$ with $\mathrm{Fe}, \mathrm{Al}$ and Ca. (Park et al., 2004).

Although compost has high levels of $\mathrm{Pi}$ as orthophosphate, this information is not time-specific, and there is little information with respect to $\mathrm{P}$ dynamics during the composting process. Frossard et al. (2002) determined $\mathrm{P}$ fractionation in compost in order to estimate $\mathrm{P}$ forms and bioavailability from various soil/compost mixtures. Studies conducted by this research group have indicated that only 30 to $50 \%$ of the total Pi in compost is rapidly plant available, suggesting that a large fraction of Pi compost is present as condensed calcium phosphates, such as apatites or octacalcium phosphate, which are not soluble in water, bicarbonate or $\mathrm{NaOH}$. Among Po species present in compost, inositol phosphate and DNA have been identified. Eghball et al. (2003), by fractionating $\mathrm{P}$ in composts and uncomposted manure, found that more than $75 \%$ of $\mathrm{P}$ in both types of manure was Pi. Po was $16 \%$ of total $\mathrm{P}$ in composted manure and $25 \%$ in noncomposted manure, which indicates that Po is mineralized during the composting process.

According to the evolution of the composting process, immature compost contains substantial amounts of easily degradable organic compounds, such as organic acids (Smith and Hughes, 2004), and has a higher microbial biomass and therefore enzymatic activity, which decreases upon the compost reaching maturity and stabilizing. Thus, the maturity or age of the compost can affect $\mathrm{P}$ availability. Adler and Sikora (2003) suggested that water-extractable P may increase when soils are amended with biologically active immature compost due to the generation of organic acids or humic substances, which can compete with adsorption sites and so generate higher available $\mathrm{P}$ in amended soil. Mkhabela and Warman (2005) studied the influence of compost from municipal solid waste on the $P$ soil dynamic, suggesting that compost may be effective as a mineral fertilizer in increasing and supplying available $\mathrm{P}$ for soil, and found that mixed soil-compost increases $\mathrm{pH}$ in the range of 0.2-0.6 units in soil with an initial $\mathrm{pH}$ of 5.8. The authors also indicated that $\mathrm{P}$ fixation was slightly decreased (78\% fixation for control to $70 \%$ for compost) with the addition of compost. They explained that organic materials may enhance soil $\mathrm{P}$ availability because of the organic acids present in wastes, as well as the increasing $\mathrm{pH}$ due to $\mathrm{C}$ mineralization and hydroxyl ion production; however the incorporation of cations such as $\mathrm{Ca}$ and $\mathrm{Mg}$ may decrease $P$ availability.

Enzymatic activity also depends on the quantity of microbial biomass contained in wastes. Higher microbial activity after compost application increases phosphatase activity and thus releases $\mathrm{P}$ during the decomposition of organic matter. Pascual et al. (2002) proposed that changes in soil phosphatase activity are dependent upon the degree of stabilization of residues. When fresh residues are applied to soil, the phosphatase activity initially increases compared with mature compost; over time 
(360 days), however, this activity decreases. However, the soil amended with compost did not show a decrease in activity. The authors pointed out that mature compost to protect enzymes against degradation due to the immobilization process. Park et al. (2004) demonstrated that compost and a mixture of compost and fertilizer increased total organic and available P. The authors also indicated that when $\mathrm{P}$ is applied from compost or fertilizer, it can inhibit phosphatase activity and subsequently suppress the mineralization processes, favoring Po accumulation. García-Gil et al. (2000) found phosphatase activity was inhibited in organically amended soil when incorporating municipal solid residue compost, suggesting that phosphatase activity can be inhibited by heavy metals and also by Pi feedback, as this enzyme is activated by low $\mathrm{P}$ availability in soil.

\section{PROSPECTIVE STUDIES}

This study shows that the current trend is to maximize the use of $\mathrm{P}$ from residues. This makes necessary a knowledge of the $\mathrm{P}$ species, their evolution, their interactions in residues and their subsequent fate in the soil environment.

In terms of crop land application, it is important to highlight that the factors that determine $\mathrm{P}$ bioavailability in soil should be studied to learn more about their influence on $\mathrm{P}$ bioavailability in organic residues. In the course of our investigation, we noted that the evolution and dynamics of $\mathrm{P}$ in organic waste has not been thoroughly studied, especially the stages of maximum $\mathrm{P}$ bioavailability in the degradation process related to phosphatase activity and organic acids. This information could help to optimize the use of $\mathrm{P}$ from organic residues.

\section{ACKNOWLEDGMENTS}

Authors thank: Laboratorio de Suelos, Universidad de La Frontera. Grant Project MECESUP FRO 0309, Grant CONICYT AT-24060247 and the International Cooperation Project FONDECYT 7020934.

\section{REFERENCES}

ADLER, P. R. AND SIKORA L. J. 2003. Changes in soil phosphorus availability with poultry compost age. Commun. Soil Sci. Plant Anal. 34(1\&2): 81-95.

ADNAN, A., MAVINIC, D. S. AND KOCH, F. A. 2003. Pilot-scale study of phosphorus recovery through struvite crystallization - examining the process feasibility. J. Environ. Eng. Sci. 2: 315-324.

AJIBOYE, B., AKINREMI, O. O. AND RACZ，G. J. 2004. Laboratory characterization of phosphorus in fresh and over-dried organic amendment. J. Environ. Qual. 33: 1062-1069.

AKHTAR, M. MCCALLISTER, D. L. AND ESKRIDGE, K. M. 2002. Availability and fractionation of phosphorus in sewage sludgeamended soils. Commun. Soil Sci. Plant Anal. 33(13\&14): 2057-2068.

ATIA. A. M. AND MALLARINO, A. P. 2002. Agronomic and environmental soil phosphorus testing in soils receiving liquid swine manure. Soil Sci. Soc. Am. J. 66: 1696-1705.

BAEZA, G. 2001. Un modelo para el reciclaje de nitrógeno, fósforo y azufre en el sistema suelo-planta-animal en suelos ácidos. Tesis de Doctorado. Universidad de Santiago. Chile. 
BALMÉR, P. 2004. Phosphorus recoveryan overview of potentials and possibilities. Wat. Sci. Technol. 49 (10): 185-190.

BARNETT, G. M. 1994a. Phosphorus forms in animal manure. Biores. Technol. 49: 139-147.

BARNETT, G. M. 1994b. Manure P fractionation. Biores. Technol. 49: 149-155.

BARROW, N. J. 1975. Chemical form of organic phosphate in sheep faeces. Aust. J. Soil. Res. 13: 63-67.

BENITO, M., MASAGUER, A., MOLINER, A., ARRIGO, N. AND PALMA, R. M. 2003. Chemical and microbiological parameters for the characterisation of the stability and maturity of pruning waste compost. Biol. Fertil. Soils. 37: 184-189.

BOLAN, N. S., NAIDU, R., MAHIMAIRAJA, S. AND BASKARAN, S. 1994. Influence of low-molecular-weight organic acid on the solubilization of phosphates. Biol. Fertil. Soils. 18(4): 311-319.

BOLAN N. S. AND DURAISAMY, P. 2003. Role of inorganic and organic soil amendments on immobilisation and phytoavailability of heavy metals: a review involving specific case studies. Aust. J. Soil Res. 41(3): 533-555.

BOLAN, N. S., ADRIANO, D. C., NAIDU, R., MORA, M. L., MAHIMAIRAJA, S. Phosphorus-trace element interactions in soil-plant systems. In Phosphorus: Agriculture and the environment. Edited by J. Thomas Sims, Andrew N. Sharpley, G.M. Pierzynski, D.T. Westermann, M.L. Cabrera, J.M. Powell, T.C. Daniel, and P.J.A. Withers. 2005. Hardcover, 1121 pages, ASA-CSSA-SSSA, Agron. Monogr. 46. ISBN: 0-89118157-1.Chapter 10. pp: 317-352. USA Publishers.
BORIE, F., REDEL. Y., RUBIO, R., ROUANET, J. L. AND BAREA, J. M. 2002. Interactions between crop residues application and mycorrhizal developments and some soil-root interface properties and mineral acquisition by plants in an acidic soil. Biol. Fertil. Soils. 36: 151-160.

BORIE, F. \& RUBIO, R. 2003. Total and organic phosphorus in Chilean volcanic soils. Gayana Bot. 60(1): 69-78.

BRICEÑO, M., ESCUDEY, M., GALINDO, G., BORCHARDT, D. AND CHANG. A. 2004. Characterization of chemical phosphorus forms in volcanic soils using 31P-NMR spectroscopy. Commum. Soil Sci. Plant Anal. 35: (9\&10), 1323-1337.

BURNS, R. T., MOODY, L. B., CELEN, I. AND BUCHANAN, J. R. 2003. Optimization of phosphorus precipitation from swine manure slurries to enhance recovery. Wat. Sci. Technol. 48: 1: 139-146.

CHEN, C. R., SINAJ. S., CONDRON. L. M., FROSSARD. E., SHERLOCK, R. R. AND DAVIS, M. R. 2003. Characterization of phosphorus availability in selected New Zealand grassland soils. Nutr. Cycl. Agroecosys. 65: 89-100.

DE BROUWERE, K., THIJS, A., HENS, M. \& MERCKX, R. 2003. Forms and bioavailability of soil phosphorus in temperate forests in southern Chile and Flanders. Gayana Bot. 60 (1), 17-23.

DENG, S. P. AND TABATABAI, M. A. 1997. Effect of tillage and residue management on enzyme activities in soils:III.Phosphatases and arylsulfatase. Biol. Fertil Soils. 24: 141-146.

DEROUCHEY, J. M., GOODBAND, R.D., NELSSEN, J. L., TOKACH, M. D., DRITZ, S. S. AND MURPHY, J. P. 2002. Nutrient composition of Kansas 
swine lagoons and hoop barn manure.

J. Anim. Sci. 80: 2051-2061.

DING, L., WANG, X., ZHU, Y., EDWARDS, M., GLINDEMANN, D. AND REN, H. 2005. Effect of $\mathrm{pH}$ on phosphine production and the fate of phosphorus during anaerobic process with granular sludge. Chemosphere 59: 49-54.

EBELING, A. M., BUNDY, L. G., POWELL, J. M. AND ANDRASKI, T. W. 2002. Dairy diet phosphorus effects on phosphorus losses in runoff from land-applied manure. Soil. Sci. Soc. Am. J. 66: 284-291.

EGHBALL, B. 2003. Leaching of phosphorus fractions following manure or compost application. Commun. Soil. Sci. Plant Anal. 34 (19\&20): 2803-2815.

FROSSARD, E., SKRABAL, P., SINAJ, S., BANGERTER, F. \& TRAORÉ, O. 2002. Forms and exchangeability of inorganic phosphate in composted solid organic wastes. Nutr. Cycl. Agroecosys. 62: 103-113.

GALE, P. M., MULLEN, M. D., CIESLIK, C., TYLER, D. D., DUCK, B. N., KIRCHNER, M. AND MCCLURE, J. 2000. Phosphorus distribution and availability is response to dairy manure applications. Commun. Soil. Sci. Plant Anal. 31(5\&6): 553-565.

GARCÍA-GIL, J. C., PLAZA, C., SOLERROVIRA,P.ANDPOLO,A. 2000.Longterm effects of municipal solid waste compost application on soil enzyme activities and microbial biomass. Soil Biol. Biochem. 32: 1907- 1913.

GARCÍA-GIL, J.C., CEPPI, S. B., VELASCO, M. I., POLO, A. AND N. SENESI. 2004. Long- term effects of amendment with municipal solid waste compost on the elemental and acidic functional group composition and $\mathrm{pH}$-buffer capacity of soil humic acids. Geoderma. 121: 135-142.
GARRIDO, S. E., VILCHIS, J., ANDRÉ, C., GARCÍA, J., ALVAREZ, A. AND GOROSTIETA, E. 2002. Aerobic thermophilic composting of waste sludge from gelatin-grenetine industry. Resources, Conservation and Recycling. 34: 161-173.

GEELHOED, J. S., VAN RIEMSDIJK, W. H. \& FINDENEGG, G. R. 1999. Simulation of the effect of citrate exudation from roots on the plant availability of phosphate adsorbed on goethite. Eur. J. Soil Sci. 50: 379-390.

GREAVES, J., HOBBS, P., CHADWICK, D. AND HAYGARTH, P. 1999. Prospect for the recovery of phosphorus from animal manures: A review. Environ. Technol. 20: 697-708.

GRIFFIN, T. S., HONEYCUTT, C. W. AND HE, Z. 2003. Changes in soil phosphorus from manure application. Soil Sci. Soc. Am. J. 67: 645-653.

HANSEN, J. C., CADE-MENUN, B. J. AND STRAWN D. G. 2004. Phosphorus speciation in manureamended alkaline soils. J. Environ. Qual. 33: 1521- 1527.

HAYGARTH, P. M. AND JARVIS, S. C. 1997. Soil derived phosphorus in surface runoff from grazed grassland lysimeters. Wat. Res. 31(1): 140-148.

HAYES, J. E., RICHARDSON, A. E. AND SIMPSON, R. J. 2000. Components of organic phosphorus in soil extracts that are hydrolysed by phytase and acid phosphatase. Biol. Fertil. Soils. 32: 279-286.

HAYNES, R. J. \& MOKOLOBATE, M.S. 2001. Amelioration of Al toxicity and $P$ deficiency in acid soils by additions of organic residues: a critical review of the phenomenon and the mechanisms involved. Nutr. Cycl. Agroecosys. 59: 47-63. 
HE, Z., HONEYCUTT, C. W AND GRIFFIN T. S. 2003. Comparative investigation of sequentially extracted phosphorus fractions in a sandy loam soil and a swine manure. Commun. Soil. Sci. Plant Anal. 34(11\&12): 1729-1742.

HE, Z., GRIFFIN, T. S. AND HONEYCUTT, C.W. 2004. Phosphorus distribution in dairy manures. J. Environ. Qual. 33(4): 1528-1534.

HEDLEY, M. J., STEWART, J. W. B. AND CHAUHAN, B. S. 1982. Changes in inorganic and organic soil phosphorus fractions induced by cultivation practices and by laboratory incubations. Soil Sci. Soc. Am. J. 46: 970-976.

HINSINGER, P. 2001. Bioavailability of soil inorganic $\mathrm{P}$ in the rhizosphere as affected by root-induced chemical changes: a review. Plant Soil. 237: 173-195.

HODGKINSON, R. A., CHAMBERS, B. J., WITHERS, P. J. A. AND CROSS, R. 2002. Phosphorus losses to surface waters following organic manure applications to drained clay soil. Agricultural Water Management. 57: 155-173.

IYAMUREMYE, F., DICK, R. P. AND BAHAM. J. 1996a. Organic amendments and phosphorus dynamics: I. Phosphorus chemistry and sorption. Soil Sci. 161(7): 426-435.

IYAMUREMYE, F., DICK, R. P. AND BAHAM. J. 1996b. Organic amendments and phosphorus dynamics: II. Distribution of soil phosphorus fractions. Soil Sci. 161(7): 436-443.

IYAMUREMYE, F., DICK, R. P. AND BAHAM. J. 1996c. Organic amendments and phosphorus dynamics:III. Phosphorus speciation. Soil Sci. 161(7): 444-451.
JARA, A., VIOLANTE. A., PIGNA, M. AND MORA, M. L. 2005. Mutual interactions of sulfate, oxalate, citrate and phosphate on synthetic and natural allophanes. Soil Sci. Soc. Am. J. 70: 337- 346.

JONES, D. L. 1998. Organic acid in the rhizosphere - a critical review. Plant Soil. 205: 25-44.

JONES, D. L., DENNIS, P.G., OWEN, A. G. \& VAN HEES, P. A. W. 2003. Organic acid behavior in soils misconceptions and knowledge gaps. Plant and Soil. 248: 31-41.

KWABIAH, A. B., STOSKOPF, N. C., PALM, C. A., VORONEY, R. P., RAO, M. R. AND GACHERU, E. 2003a. Phosphorus availability and maize response to organic and inorganic fertilizer inputs in a short term study in western Kenya. Agric. Ecosys. Environ. 95: 49-59.

KWABIAH, A. B., PALM, C. A., STOSKOPF, N.C.ANDVORONEY, R. P. 2003b. Response of soil microbial biomass dynamic to quality of plant materials with emphasis on Pavailability. Soil Biol. Biochem. 35: 207-216.

LABOSKI, C. A. M. AND LAMB, J. A. 2003. Changes in soil test phosphorus concentration after application of manure or fertilizer. Soil. Sci. Soc. Am. J. 67: 544-554.

LEINWEBER, P., HAUMAIER, L. AND ZECH, W. 1997. Sequential extractions and 31P-NMR spectroscopy of phosphorus forms in animal manures, whole soils and particle-size separates from a densely populated livestock area in northwest Germany. Biol. Fertil. Soils. 25: 89-94.

LEVLIN, E., LÖWÉN, M., STARK, K. AND HULTMAN. B. 2002. Effects of phosphorus recovery requirements on Swedish sludge management. Wat. Sci. Technol. 46(4): 435-440. 
LINQUIST, B. A., SINGLETON, P. W. AND CASSMAN. K. G. 1997. Inorganic and organic phosphorus dynamic during a build-up and decline of available phosphorus in an ultisol. Soil Sci. 162(4): 254-264. MAKAROV, M. I., HAUMAIER, L., ZECH, W., MARFENINA, O. E. AND LYSAK, L. V. 2005. Can 31P NMR spectroscopy be used to indicate the origins of soil organic phosphates? Soil Biol. Biochem. 37: 15-25. MALLEY, D. F., YESMIN, L. AND.

EILERS. R. G. 2002. Rapid analysis of hog manure and manure-amended soils using near-infrared spectroscopy. Soil Sci. Soc. Am. J. 66: 1677-1686.

MARINARI, S., MANCINELLI, R., CAMPIGLIA, E. AND GREGO, S. 2006. Chemical and biological indicators of soil quality in organic and conventional farming systems in Central Italy. Ecological Indicators 6: 701-711.

MCDOWELL, R.W. AND STEWART, I. 2005. Phosphorus in fresh and dry dung of grazing dairy cattle, deer, and sheep: Sequential fraction and phosphorus-31 nuclear magnetic resonance analyses. J. Environ. Qual. 34: 598-607.

MKHABELA, M. S. AND WARMAN, P. R. 2005. The influence of municipal solid waste compost on yield, soil phosphorus availability and uptake by two vegetable crops grown in a Pugwash sandy loam soil in Nova Scotia. Agric. Ecosys. Environ. 106: 57-67.

MOKOLOBATE, M. S. AND HAYNES, R. J. 2002. Comparative liming effect of four organic residues applied to an acid soil. Biol. Fertil. Soils. 35: 79- 85

MORA, M. L. AND CANALES. J. 1995a. Interactions of humic substances with allophanic compounds. Commun. Soil. Sci. Plant Anal. 26(17\&18): 2805-2817.
MORA, M. L. AND CANALES. J. 1995 b. Humin-clay interactions on surface reactivity in Chilean Andisols. Commun. Soil. Sci. Plant Anal. 26(17\&18): 2819-2828.

NELSON, N. O., MIKKELSEN, R. L. AND HESTERBERG, D. L. 2003. Struvite precipitation in anaerobic swine lagoon liquid: effect of $\mathrm{pH}$ and $\mathrm{Mg}: \mathrm{P}$ ratio and determination of rate constant. Biores. Technol. 89: 229-236.

NWOKE, O. C., VANLAUWE, B., DIELS, J., SANGINGA, N., OSONUBI, O. AND MERCKX, R. 2003. Assessment of labile phosphorus fractions and adsorption characteristics in relation to soil properties of West African savanna soils. Agric. Ecosys. Environ. 100: 285-294.

OEHL, F., OBERSON, A., PROBST, M., FLIESSBACH, A., ROTH, H. R. AND FROSSARD, E. 2001. Kinetics of microbial phosphorus uptake in cultivated soils. Biol. Fertil. Soils. 34: 31-41.

OEHL, F., FROSSARD, E., FLIESSBACH, A., DUBOIS, D. AND OBERSON, A. 2004. Basal organic phosphorus mineralization in soils under different farming systems. Soil Biol. Biochem. 36: 667-675.

PANDEY, A., SZAKACS, G., SOCCOL, C. R., RODRIGUEZ-LEON, J. A. AND SOCCOL, V. T. 2001. Production, purification and properties of microbial phytases. Biores. Technol. 77, 203-214.

PANT, H. K. AND WARMAN, P. R. 2000. Enzymatic hydrolysis of soil organic phosphorus by immobilized phosphatases. Boil. Fertil Soils. 30: 306-311.

PARFITT, R. L., YEATES, G. W., ROSS, D. J., MACKAY, A. D. AND BUDDING, P. J. 2005. Relationships 
between soil biota, nitrogen and phosphorus availability, and pasture growth under organic and conventional management. Appl. Soil Ecol. 28: 1-13.

PARK, M., SINGVILAY, O., SHIN, W., KIM. E., CHUNG, J AND SA, T. 2004. Effect of long-term compost and fertilizer application on soil phosphorus status under paddy cropping system. Commun. Soil Sci. Plant Anal. 35(11\&12): 1635-1644.

PASCUAL, J. A., MORENO, J. L., HERNÁNDEZ, T. AND GARCÍA, C. 2002. Persistence of immobilized and total urease and phosphatase activities in a soil amended with organic wastes. Biores. Technol. 82: 73-78.

PYPERS, P., VERSTRAETE, S., THI, C. P. AND MERCKX, R. 2005. Changes in mineral nitrogen, phosphorus availability and salt-extractable aluminium following the application of green manure residues in two weathered soils of South Vietnam. Soil Biol. Biochem. 37: 163-172.

RAO, M. A., VIOLANTE, A. AND GIANFREDA, L. 2000. Interaction of acid phosphatase with clays, organic molecules and organo-mineral complexes: kinetic and stability. Soil Biol. Biochem. 32: 1007-1014.

REBOLLAR, P.G. Y MATEOS, G. G. 1999. El fósforo en nutrición animal. Necesidades, valoración de materias primas y mejora de la disponibilidad. En Curso de Especialización FEDNA: Avances en nutrición y alimentación animal. Fundación Española para el Desarrollo de la Nutrición Animal. Eds.: P.G. Rebollar, C. de Blas y G.G. Mateos. Madrid, España.

RYDIN, E. 1996. Experimental studies simulating potential phosphorus release from municipal sewage sludge deposits. Wat. Res. 30(7): 1695-1701.
SCHERER, H. W. AND SHARMA, S. P. 2002. Phosphorus fractions and phosphorus delivery potential of a luvisol derived from loess amended with organic materials. Biol. Fertil. Soils. 35: 414-419.

SHAND, C. A. AND SMITH, S. 1997. Enzymatic release of phosphate from model substrates and $\mathrm{P}$ compounds in soil solution from a peaty podzol. Biol. Fertil Soils. 24: 183-187.

SHARPLEY, A. N., MCDOWELL, R. W. AND KLEINMAN, P. J. A. 2004. Amount, forms, and solubility of phosphorus in soils receiving manure. Soil Sci. Soc. Am. J. 68: 2048-2057.

SHIMAMURA, K., TANAKA, T., MIURA, Y. AND ISHIKAWA, H. 2003. Development of a high-efficiency phosphorus recovery method using a fluidized-bed crystallized phosphorus removal system. Wat. Sci. Techol. 48(1): 163-170.

SMITH, D. C. AND HUGHES, J. C. 2004. Changes in maturity indicators during the degradation of organic wastes subjected to simple composting procedures. Biol. Fertil. Soils. 39: 280-286.

SPEIR, T. W., HORSWELL, J., VAN SCHAIK, A. P., MCLAREN, R. G. AND FIETJE, G. 2004. Composted biosolids enhance fertility of a sandy loam soil under dairy pasture. Biol. Fertil. Soil. 40: 349-358.

STRÖM, L., OWEN, A. G., GODBOLD, D. L. AND JONES, D. L. 2002. Organic acid mediated $P$ mobilization in the rhizosphere and uptake by maize roots. Soil Biol. Biochem. 34: 703-710.

SZÖGI, A. A., VANOTTI, M. B. AND HUNT, P. G. 2006. Dewatering of phosphorus extracted from liquid swine waste. Biores. Technol. 97(1): 183-190. 
TAIZ, L. AND ZEIGER, E. 1998. Plant physiology. Second edition. Sinauer Associates, Inc. Publishers. Massachusetts. USA. 792 pp.

THIEN, S. J. AND MYERS, R. 1992. Determination of bioavailable phosphorus in soil. Soil. Sci. Soc. Am. J. 56: 814- 818 .

TOOR, G. S., HUNGER, PEAK, J. D., SIMS, J. T. AND SPARKS, D. L. 2006. Advances in the characterization of phosphorus in organic wastes: Environmental and agronomic applications. Advances in Agronomy. 89: 1-72

TRAORÉ, O., SINAJ, S., FROSSARD, E. AND VAN DE KERKHOVE, J. M. 1999. Effect of composting time on phosphate exchangeability. Nutr. Cycl. Agroecosys.55: 123-131.

TURNER, B. L., PAPHÁZY, M. J., HAYGARTH, P. M. AND MCKELVIE, I. D. 2002. Inositol phosphates in the environment. Phil. Trans. R. Soc. Lond. B. 357: 449-469.

TURNER, B. L, MAHIEU, N. AND CONDRON, L. M. 2003a. Phosphorus-31 nuclear magnetic resonance spectral assignments of phosphorus compounds in soil $\mathrm{NaOH}$ EDTA extracts. Soil Sci. Soc. Am. J. 67:497-510.

TURNER, B. L, MAHIEU, N. AND CONDRON L. M. 2003b. The phosphorus composition of temperate pasture soils determined by $\mathrm{NaOH}$ -
EDTA extraction and solution 31P NMR spectroscopy. Organic Geochem. 34: 1199-1210.

VASSILEV, N., VASSILEVA, M., FENICE, M. AND FEDERICI F. 2001. Immobilized cell technology applied in solubilization of insoluble inorganic (rock) phosphates and P plant acquisition. Biores. Technol. 79: 263-271

VERMA, S., SUBEHIA, S. K. AND SHARMA, S. P. 2005. Phosphorus fractions in an acid soil continuously fertilized with mineral and organic fertilizers. Biol. Fertil Soils. 41: 295-300.

WIENHOLD. B. J. 2005. Changes in soil attributes following low phosphorus swine slurry applications to no-tillage sorghum. Soil Sci. Soc. Am. J. 69: 206-214.

WITHERS, P. J. A., EDWARDS, A. C. \& FOY, R. H. 2001. Phosphorus cycling in UK agriculture and implications for phosphorus loss from soil. Soil Use and Management. 17: 139-149.

XU, R., ZHAO, A. AND JI, G. 2003. Effect of low-molecular-weight organic anions on surface charge of variable charge soils. J. Colloid and Interface Sci. 264: 322-326.

YADAV, R. S. AND TARAFDAR, J. C. 2003. Phytase and phosphatase producing fungi in arid and semi-arid soils and their efficiency in hydrolyzing different organic Pcompounds. Soil Biol. Biochem. 35: 1-7. 